ISSN 0258-7122

Bangladesh J. Agril. Res. 39(2): 211-225, June 2014

\title{
TOTAL DRY MATTER PRODUCTION OF POTATO, MUNGBEAN AND T. AMAN RICE AS INFLUENCED BY NUTRIENT MANAGEMENT OF POTATO-MUNGBEAN-T. AMAN RICE CROPPING PATTERN
}

\author{
M. A. H. S. JAHAN ${ }^{1}$, M. A. R. SARKAR ${ }^{2}$ \\ M. SALIM ${ }^{3}$, N. ISLAM ${ }^{4}$ AND T. P. TIWARI ${ }^{5}$
}

\begin{abstract}
A field experiment was conducted at the Regional Wheat Research Centre (RWRC) of the Bangladesh Agricultural Research Institute, Gazipur, Bangladesh for 2 consecutive years during 2006-07 and 2007-08 with the objective to find out the optimum nutrient management practice on total dry matter production (above ground part) of each component crop of potatomungbean-t. aman rice cropping pattern. Twelve nutrient management treatments were tested in RCBD with 3 replications. Treatments were, $\mathrm{T}_{1}=\mathrm{HYG}$ (0-198-44-194-24-6-1.2), $\quad \mathrm{T}_{2}=\mathrm{MYG} \quad(0-140-34-138-18-4.5-0.9), \quad \mathrm{T}_{3}=\mathrm{IPNS}$ (10000-168-38-170-18-6-1.2), $\mathrm{T}_{4}=\mathrm{STB}(0-171-40-164-22-5-1), \mathrm{T}_{5}=\mathrm{FP}(0-97-16$ 91-0-0-0), $\quad \mathrm{T}_{6}=\mathrm{CON} \quad(0-0-0-0-0-0-0), \quad \mathrm{T}_{7}=\mathrm{HYG}+\mathrm{CRI}, \quad \mathrm{T}_{8}=\mathrm{MYG}+\mathrm{CRI}$, $\mathrm{T}_{9}=\mathrm{IPNS}+\mathrm{CRI}, \quad \mathrm{T}_{10}=\mathrm{STB}+\mathrm{CRI}, \quad \mathrm{T}_{11}=\mathrm{FP}+\mathrm{CRI}, \quad \mathrm{T}_{12}=\mathrm{CON}+\mathrm{CRI} \quad \mathrm{kg} / \mathrm{ha}$ CDNPKSZnB, for potato; $\mathrm{T}_{1}=\mathrm{HYG}(0-24-40-48-24-3-1.2), \mathrm{T}_{2}=\mathrm{MYG}(0-20-36$ 40-20-2-1), $\mathrm{T}_{3}=$ IPNS (5000-9-37-36-21-3-1.2), $\mathrm{T}_{4}=\mathrm{STB}(0-20-36-40-22-2-1)$, $\mathrm{T}_{5}=\mathrm{FP} \quad(0-6-5-4-0-0-0), \quad \mathrm{T}_{6}=\mathrm{CON} \quad(0-0-0-0-0-0-0), \quad \mathrm{T}_{7}=\mathrm{HYG}+\mathrm{CRI}$ $\mathrm{T}_{8}=\mathrm{MYG}+\mathrm{CRI}, \mathrm{T}_{9}=\mathrm{IPNS}+\mathrm{CRI}, \mathrm{T}_{10}=\mathrm{STB}+\mathrm{CRI}, \mathrm{T}_{11}=\mathrm{FP}+\mathrm{CRI}, \mathrm{T}_{12}=\mathrm{CON}+\mathrm{CRI}$ $\mathrm{kg} / \mathrm{ha}$ CDNPKSZnB for mungbean and $\mathrm{T}_{1}=\mathrm{HYG}(0-80-16-44-12-2-0)$, $\mathrm{T}_{2}=\mathrm{MYG}(0-56-12-32-8-1.5-0), \mathrm{T}_{3}=\mathrm{IPNS}(5000-65-13-32-9-2-0), \mathrm{T}_{4}=\mathrm{STB}(0-$ 68-15-37-11-2-0), $\quad \mathrm{T}_{5}=\mathrm{FP} \quad(0-39-37-12-0-0-0), \quad \mathrm{T}_{6}=\mathrm{CON}(0-0-0-0-0-0-$ $0), \mathrm{T}_{7}=\mathrm{HYG}+\mathrm{CRI}, \mathrm{T}_{8}=\mathrm{MYG}+\mathrm{CRI}, \mathrm{T}_{9}=\mathrm{IPNS}+\mathrm{CRI}, \mathrm{T}_{10}=\mathrm{STB}+\mathrm{CRI}, \mathrm{T}_{11}=\mathrm{FP}+\mathrm{CRI}$, $\mathrm{T}_{12}=\mathrm{CON}+\mathrm{CRI} \mathrm{kg} / \mathrm{ha}$ CDNPKSZnB for t. aman rice. HYG treatment without or with crop residues incorporation produced the highest TDM in potato, mungbean and t. aman rice followed by IPNS and STB along with or without CRI. The lowest TDM was recorded in control plot without CRI. The increasing trend of TDM was observed in the crop residues incorporation plots than nonincorporation plots. It was observed that there were significant and positive linear relationship between TDM and yield of potao, mungbean, and t. aman rice at 60 DAP, 60 DAS, and 90 DAT, respectively, in both the years.
\end{abstract}

Keywords: Dry matter, potato, mungbean, t. aman rice, nutrient, and crop residue management.

\section{Introduction}

Cropping pattern at any place is the yearly sequence and spatial arrangement of crops evolved in relation to agro-climatological features, land capability, socio-

${ }^{1}$ Principal Scientific Officer, RWRC, Bangladesh Agricultural Research Institute (BARI), Gazipur, ${ }^{2,3,4 \& 5}$ Prof. Dept. of Agronomy, Bangladesh Agricultural University (BAU), Mymensingh, ${ }^{5}$ Cropping System Agronomist and CLO, CIMMYT-Bangladesh, Bangladesh. 
economic structures, technological know-how, extension infra-structure as well as national policy (Harwood, 1974; Gomez and Gomez, 1983). An effective cropping pattern ensures the best efficiency of land, labour, fertilizer, irrigation water, and other inputs (Harwood, 1974). However, farmers select crops based on many factors, such as availability of agricultural inputs, family needs, market demands, and net returns.

Potato is an important food crop in Bangladesh. It ranks third after rice and wheat. Potato is a high yield potential tuber crop and its potential yield is estimated at 25-30 t/ha in Bangladesh (Satter et al., 2005). Potato is a good source of energy and contains high levels of minerals and proteins. It provides over twice as much dry matter and calories per unit area of land and time as compared to rice or wheat (Couto et al., 1983). Potato protein has limited sulphur containing amino acids, but contains substantially more lysine compared to cereals and is thus a good food supplement (Woolf, 1987).

Mungbean is an important grain legume in Bangladesh. It is used as whole or split seeds as Dal (Soup) but in other countries sprouted seeds are widely used as vegetables. It is a major source of high quality protein. Mungbean grain contains $51 \%$ carbohydrates, $26 \%$ protein, $10 \%$ moisture, $4 \%$ mineral, and $3 \%$ vitamins. (Kaul, 1980). Pulses although fix nitrogen from the atmosphere, moreover applications of fertilizer become helpful increasing dry matter production and yield.

Rice is the primary source of dietary energy and protein for nearly three billion people in Asia. The modern methods to solve food problems (human and animal) always tend to neglect the protein concept and its substitute with a definite biological value of protein (Islam, 2008). Fertilizers and residual benefit of crop residues incorporation is commonly assessed mainly in terms of increased grain yield, plant height and dry matter production (Islam, 2008).

Most of the nutrient recommendations have been designed based on sole or mono-crop basis. but information regarding nutrient requirement and its management practices for particular cropping pattern for certain location is meager. Dry matter production is one of the most important factors for yield of any crop. Therefore, the present study was undertaken with objectives to find out the optimum nutrient management practice for crop yield as well as to make a relationship between maximum TDM production per unit area and irrespective yield of each component crop of potato-mungbean-T. Aman rice cropping pattern.

\section{Materials and Method}

The experiment was carried out at the Regional Wheat Research Centre of Bangladesh Agricultural Research Institute, Joydebpur, Gazipur. The 
experimental field of Gazipur belongs to the agro-ecological zone of Modhupur Tract (AEZ-28). The initial soil of the experimental field was analyzed for chemical properties before setting up the experiment. The initial soil status was $\mathrm{pH} 6.48$, OM (\%) 1.07, Total N (\%) 0.055, available $\mathrm{P}(\mu \mathrm{g} / \mathrm{g}) 3.76$, exchangable $\mathrm{K}(\mathrm{meq} / 100 \mathrm{~g}) 0.15$, available $\mathrm{S}(\mu \mathrm{g} / \mathrm{g}) 9.91$, available $\mathrm{Zn}(\mu \mathrm{g} / \mathrm{g}) 0.24$, and available B $(\mu \mathrm{g} / \mathrm{g})$ 0.16. Morphological characters are Grey Terrace soils, medium high land, not well drained, above flood level and grey soil clour. Physiological characters are silty loam to loam having more or less near neutral soil pH with very low to low soil fertility. Potato (BARI-Alu 8, Cardinal), mungbean (BARI Mung-6) and t. aman rice (BRRI dhan39) varieties were tested in Rabi, Kharif-I, and Kharif-2 seasons, respectively, for 2006-07 and 2007-08. Twelve nutrient management treatments were tested in RCBD with 3 replications. Treatments were $\mathrm{T}_{1}=\mathrm{HYG}(0-198-44-194-24-6-1.2), \mathrm{T}_{2}=\mathrm{MYG}(0-$ 140-34-138-18-4.5-0.9), $\mathrm{T}_{3}=\mathrm{IPNS} \quad(10000-168-38-170-18-6-1.2), \quad \mathrm{T}_{4}=\mathrm{STB} \quad(0-$ 171-40-164-22-5-1), $\quad \mathrm{T}_{5}=\mathrm{FP} \quad(0-97-16-91-0-0-0), \quad \mathrm{T}_{6}=\mathrm{CON} \quad(0-0-0-0-0-0-0)$, $\mathrm{T}_{7}=\mathrm{HYG}+\mathrm{CRI}, \mathrm{T}_{8}=\mathrm{MYG}+\mathrm{CRI}, \mathrm{T}_{9}=\mathrm{IPNS}+\mathrm{CRI}, \mathrm{T}_{10}=\mathrm{STB}+\mathrm{CRI}, \mathrm{T}_{11}=\mathrm{FP}+\mathrm{CRI}$, $\mathrm{T}_{12}=\mathrm{CON}+\mathrm{CRI} \mathrm{kg} / \mathrm{ha}$ CDNPKSZnB, for potato; $\mathrm{T}_{1}=\mathrm{HYG}(0-24-40-48-24-3-1.2)$, $\mathrm{T}_{2}=$ MYG $(0-20-36-40-20-2-1), \mathrm{T}_{3}=$ IPNS $(5000-9-37-36-21-3-1.2), \mathrm{T}_{4}=\mathrm{STB}(0-$ 20-36-40-22-2-1), $\quad \mathrm{T}_{5}=\mathrm{FP} \quad(0-6-5-4-0-0-0), \quad \mathrm{T}_{6}=\mathrm{CON} \quad(0-0-0-0-0-0-0)$, $\mathrm{T}_{7}=\mathrm{HYG}+\mathrm{CRI}, \mathrm{T}_{8}=\mathrm{MYG}+\mathrm{CRI}, \mathrm{T}_{9}=\mathrm{IPNS}+\mathrm{CRI}, \mathrm{T}_{10}=\mathrm{STB}+\mathrm{CRI}, \mathrm{T}_{11}=\mathrm{FP}+\mathrm{CRI}$, $\mathrm{T}_{12}=\mathrm{CON}+\mathrm{CRI} \mathrm{kg} / \mathrm{ha}$ CDNPKSZnB for mungbean and $\mathrm{T}_{1}=\mathrm{HYG}(0-80-16-44-$ 12-2-0), $\quad \mathrm{T}_{2}=\mathrm{MYG} \quad(0-56-12-32-8-1.5-0), \quad \mathrm{T}_{3}=\mathrm{IPNS} \quad(5000-65-13-32-9-2-0)$, $\mathrm{T}_{4}=$ STB $(0-68-15-37-11-2-0), \mathrm{T}_{5}=\mathrm{FP}(0-39-37-12-0-0-0), \mathrm{T}_{6}=\mathrm{CON}(0-0-0-0-0-0-$ $0), \mathrm{T}_{7}=\mathrm{HYG}+\mathrm{CRI}, \mathrm{T}_{8}=\mathrm{MYG}+\mathrm{CRI}, \mathrm{T}_{9}=\mathrm{IPNS}+\mathrm{CRI}, \mathrm{T}_{10}=\mathrm{STB}+\mathrm{CRI}, \mathrm{T}_{11}=\mathrm{FP}+\mathrm{CRI}$, $\mathrm{T}_{12}=\mathrm{CON}+\mathrm{CRI} \mathrm{kg} / \mathrm{ha}$ CDNPKSZnB for $\mathrm{t}$. aman rice. Residue of each crop was in-situ incorporated to the soil for crop residue incorporation plots. The crops were weeded and irrigated whenever required. The crops were harvested at full maturity. Total dry matter (TDM, $\mathrm{g} / \mathrm{m}^{2}$ ) of above ground parts was calculated in the research field at every 10-day intervals for potato and mungbean and every 15-day intervals for t. aman rice started from 30 days after planting, sowing, and transplanting for potato, mungbean, and t. aman rice, respectively. Five hills for potato and t.aman rice and five plants for mungbean were randomly selected from each plot and cut it down at ground level. The plant samples were oven dried at $70{ }^{\circ} \mathrm{C}$ for 72 hours. Afterwards, the samples were taken out of the oven and kept under air for a while to get back to normal condition. The data were analyzed statistically and the mean comparisons of the treatments were evaluated by DMRT (Duncan's Multiple Range Test).

\section{Results and Discussion}

\section{Potato}

The TDM accumulation $\left(\mathrm{g} / \mathrm{m}^{2}\right)$ of potato was significantly influenced by different nutrient management treatments at all days after planting (DAP) in both the years (Table 2). 
In 2006-07, the highest TDM at 30,40,50,60,70, and 80 days after planting was produced in HYG+CRI, which was statistically identical to HYG followed by IPNS+CRI. The STB, MYG, and FP treatments without or with CRI produced TDM in the range of $44-89 \mathrm{~g} / \mathrm{m}^{2}$ at $30 \mathrm{DAP}, 74-129 \mathrm{~g} / \mathrm{m}^{2}$ at $40,140-150 \mathrm{~g} / \mathrm{m}^{2}$ at 50 DAP, $167-307 \mathrm{~g} / \mathrm{m}^{2}$ at 60 DAP, $42-129 \mathrm{~g} / \mathrm{m}^{2}$ at 70 DAP and $26-102 \mathrm{~g} / \mathrm{m}^{2}$ at 80 DAP.. The control treatment without CRI had the lowest TDM in all days after planting. Similar trend was found in 2007-08.

The overall results showed that the treatment HYG along with or without CRI produced the highest total dry matter that might be due to the effect of proper amount of nutrient, especially nitrogen dose that was followed by IPNS and STB without or with crop residues incorporation. That proper amount of nutrients might have produced maximum total dry matter in both the years. Similar result was reported in potato crop by Biswas (2011). Total dry matter production progressively increased with the advancement of time that might be due to the accumulation of total dry matter production up to 60 DAP. The dry matter was decreased at 70 and $80 \mathrm{DAP}$ which might be due to leaf senescence in that stage. It was also observed that total dry matter production was higher in 2007-08 than 2006-07. However, in both the years, the trend of the total dry matter production was increasing in all the nutrient management treatments when crop residues were incorporated than without incorporation that might be due to addition of extra nutrient from crop residues (Table 1).

HYG (High Yield Goal) =0-198-44-194-24-6-1.2, MYG( Moderate Yield Goal) $=0-140-34-138-18-4.5-0.9$, IPNS (Integrated Plant Nutrient System) $=10000-168-38-170-18-6-1.2$, STB $($ Soil Test Based $)=0-171-40-164-22-5-1$, FP (Farmer's practice $)=0-97-16-91-0-0-0, \mathrm{CON}($ Control $)=0-0-0-0-0-0-0, \mathrm{CD}, \mathrm{N}, \mathrm{P}$, $\mathrm{K}, \mathrm{S}, \mathrm{Zn}, \mathrm{B}$ (kg/ha), respectively, and CRI= Crop residue incorporation

\section{Functional relationship between TDM and tuber yield of potato}

Regression analysis (two years' mean data) was done to quantify the relationship between total dry matter at $60 \mathrm{DAP}$ and tuber yield of potato. In case of potato crop, it was noticed that more or less maximum TDM $\left(\mathrm{g} / \mathrm{m}^{2}\right)$ from above ground part was produced at 60 DAP in both the years as influenced by different nutrient management practices. Therefore, this stage (60 DAP) was considered to establish a functional relationship between TDM and tuber yield (two years' mean data). It was observed that there was a positive linear relationship between TDM at 60 DAP and the tuber yield (Fig. 1). The functional relationship suggested that $84 \%$ $\left(\mathrm{R}^{2}=0.8408\right)$ of variation of tuber yield could be explained from the variation of total dry matter accumulation at 60 DAP. On an average, tuber yield could be increased at the rate of $0.0926 \mathrm{t} / \mathrm{ha}$ with an increase in $1 \mathrm{~g} / \mathrm{m}^{2}$ of TDM at 60 DAP. From the non-liner curve, it was revealed that maximum tuber yield was obtained when TDM was produced about $325 \mathrm{~g} / \mathrm{m}^{2}$ at $60 \mathrm{DAP}$ then the trend 
Table 1. Total addition of extra nutrients into the soil through crop residues incorporation (kg/ha/yr) during 2006-07 and 20072008 (Assuming nitrogen mineralization rate 40\%).

\begin{tabular}{c|c|c|c|c|c|c|c|c|c|c|c|c}
\hline \multirow{2}{*}{$\begin{array}{c}\text { Nutrient } \\
\text { management }\end{array}$} & \multicolumn{1}{c}{$2006-2007$} & \multicolumn{4}{c|}{$2007-2008$} \\
\cline { 2 - 13 } & $\mathrm{N}$ & $\mathrm{P}$ & $\mathrm{K}$ & $\mathrm{S}$ & $\mathrm{Zn}$ & $\mathrm{B}$ & $\mathrm{N}$ & $\mathrm{P}$ & $\mathrm{K}$ & $\mathrm{S}$ & $\mathrm{Zn}$ & $\mathrm{B}$ \\
\hline HYG+CRI & 12.74 & 6.02 & 31.55 & 5.40 & 0.15 & 0.09 & 16.46 & 7.01 & 35.53 & 5.75 & 0.18 & 0.10 \\
MYG+CRI & 10.75 & 5.33 & 26.74 & 4.91 & 0.14 & 0.08 & 13.15 & 6.18 & 30.04 & 5.55 & 0.14 & 0.08 \\
IPNS+CRI & 12.19 & 6.50 & 31.40 & 5.32 & 0.15 & 0.08 & 17.02 & 7.96 & 37.36 & 6.00 & 0.18 & 0.11 \\
STB+CRI & 12.15 & 6.91 & 32.91 & 5.98 & 0.14 & 0.09 & 15.84 & 8.02 & 38.75 & 6.92 & 0.18 & 0.11 \\
FP+CRI & 8.43 & 4.39 & 22.35 & 4.05 & 0.10 & 0.06 & 8.38 & 4.57 & 22.73 & 4.14 & 0.10 & 0.05 \\
CON+CRI & 5.12 & 2.65 & 14.99 & 2.50 & 0.06 & 0.03 & 5.50 & 2.57 & 16.24 & 2.51 & 0.06 & 0.03 \\
\hline
\end{tabular}

Table 2. Total dry matter $\left(\mathrm{g} / \mathrm{m}^{2}\right)$ of potato at different days after planting as influenced by various nutrient management treatments.

\begin{tabular}{|c|c|c|c|c|c|c|}
\hline \multirow{2}{*}{ Nutrient management } & \multicolumn{2}{|c|}{30 DAP } & \multicolumn{2}{|c|}{40 DAP } & \multicolumn{2}{|c|}{50 DAP } \\
\hline & $2006-07$ & $2007-08$ & $2006-07$ & $2007-08$ & $2006-07$ & $2007-08$ \\
\hline HYG & $139 \mathrm{a}$ & $153 \mathrm{a}$ & $241 \mathrm{a}$ & $265 \mathrm{a}$ & $257 \mathrm{a}$ & $280 \mathrm{ab}$ \\
\hline MYG & 60 def & 66 def & $84 \mathrm{e}$ & $92 \mathrm{de}$ & 180 be & $198 \mathrm{~cd}$ \\
\hline IPNS & $89 \mathrm{bc}$ & $98 \mathrm{bc}$ & $135 \mathrm{bc}$ & $149 \mathrm{bc}$ & $220 \mathrm{ab}$ & $242 \mathrm{abc}$ \\
\hline STB & $78 \mathrm{~cd}$ & $86 \mathrm{~cd}$ & $115 \mathrm{~cd}$ & $127 \mathrm{~cd}$ & $213 a b$ & $234 \mathrm{abc}$ \\
\hline FP & $44 \mathrm{f}$ & 58 ef & 74 ef & 80 ef & $140 \mathrm{~cd}$ & $154 \mathrm{de}$ \\
\hline $\mathrm{CON}$ & $42 \mathrm{f}$ & $46 \mathrm{f}$ & $51 \mathrm{f}$ & $53 \mathrm{f}$ & $107 \mathrm{~d}$ & $118 \mathrm{e}$ \\
\hline $\mathrm{HYG}+\mathrm{CRI}$ & $149 \mathrm{a}$ & $164 \mathrm{a}$ & $243 \mathrm{a}$ & $267 \mathrm{a}$ & $260 \mathrm{a}$ & $284 \mathrm{a}$ \\
\hline MYG+CRI & 68 cde & 75 cde & 94 de & $103 \mathrm{de}$ & $207 \mathrm{ab}$ & $228 \mathrm{bc}$ \\
\hline IPNS+CRI & $107 \mathrm{~b}$ & $118 \mathrm{~b}$ & $159 \mathrm{~b}$ & $175 \mathrm{~b}$ & $227 \mathrm{ab}$ & $250 \mathrm{abc}$ \\
\hline STB+CRI & $86 \mathrm{bc}$ & $95 \mathrm{c}$ & $129 \mathrm{c}$ & 142 bc & $223 a b$ & $245 a b c$ \\
\hline $\mathrm{FP}+\mathrm{CRI}$ & 55 ef & $61 \mathrm{ef}$ & 75 ef & 83 ef & $150 \mathrm{~cd}$ & $165 \mathrm{de}$ \\
\hline $\mathrm{CON}+\mathrm{CRI}$ & $43 \mathrm{f}$ & $47 \mathrm{f}$ & $52 \mathrm{f}$ & $55 \mathrm{f}$ & $127 \mathrm{~d}$ & $140 \mathrm{e}$ \\
\hline CV (\%) & 11.10 & 10.50 & 10.39 & 11.15 & 10.18 & 9.88 \\
\hline
\end{tabular}


Table 2. Cont'd.

\begin{tabular}{|c|c|c|c|c|c|c|}
\hline \multirow{2}{*}{ Nutrient management } & \multicolumn{2}{|c|}{60 DAP } & \multicolumn{2}{|c|}{70 DAP } & \multicolumn{2}{|c|}{80 DAP } \\
\hline & 2006-07 & $2007-08$ & $2006-07$ & 2007-08 & 2006-07 & 2007-08 \\
\hline HYG & $514 \mathrm{ab}$ & $565 \mathrm{ab}$ & $235 \mathrm{~b}$ & $259 \mathrm{~b}$ & $227 \mathrm{a}$ & $250 \mathrm{a}$ \\
\hline MYG & 370 def & $407 \mathrm{de}$ & $103 \mathrm{de}$ & $173 \mathrm{c}$ & $146 \mathrm{~b}$ & $161 \mathrm{~b}$ \\
\hline IPNS & $497 \mathrm{abc}$ & $547 \mathrm{ab}$ & $220 \mathrm{~b}$ & $242 \mathrm{~b}$ & $218 \mathrm{a}$ & $240 \mathrm{a}$ \\
\hline STB & 450 bcde & $495 \mathrm{bcd}$ & $129 \mathrm{~d}$ & $182 \mathrm{c}$ & $148 \mathrm{~b}$ & $163 \mathrm{~b}$ \\
\hline $\mathrm{FP}$ & $307 \mathrm{f}$ & $338 \mathrm{e}$ & 78 efg & $160 \mathrm{c}$ & $102 \mathrm{c}$ & $112 \mathrm{c}$ \\
\hline $\mathrm{CON}$ & $167 \mathrm{~g}$ & $184 \mathrm{f}$ & $42 \mathrm{~g}$ & $46 \mathrm{~d}$ & $26 \mathrm{~d}$ & $29 \mathrm{~d}$ \\
\hline $\mathrm{HYG}+\mathrm{CRI}$ & $584 \mathrm{a}$ & $642 \mathrm{a}$ & $302 \mathrm{a}$ & $332 \mathrm{a}$ & $244 \mathrm{a}$ & $268 \mathrm{a}$ \\
\hline MYG+CRI & 394 cdef & 433 cde & $111 \mathrm{de}$ & $182 \mathrm{c}$ & $146 \mathrm{~b}$ & $165 \mathrm{~b}$ \\
\hline IPNS+CRI & $510 \mathrm{ab}$ & $561 \mathrm{ab}$ & $231 \mathrm{~b}$ & $254 \mathrm{~b}$ & $226 \mathrm{a}$ & $249 \mathrm{a}$ \\
\hline $\mathrm{STB}+\mathrm{CRI}$ & $470 \mathrm{bcd}$ & $517 \mathrm{bc}$ & $177 \mathrm{c}$ & $195 \mathrm{c}$ & $215 \mathrm{a}$ & $167 \mathrm{~b}$ \\
\hline $\mathrm{FP}+\mathrm{CRI}$ & 344 ef & $348 \mathrm{e}$ & 86 ef & $195 \mathrm{c}$ & $123 \mathrm{bc}$ & $135 \mathrm{bc}$ \\
\hline $\mathrm{CON}+\mathrm{CRI}$ & $170 \mathrm{~g}$ & $187 \mathrm{f}$ & $55 \mathrm{fg}$ & $61 \mathrm{~d}$ & $34 \mathrm{~d}$ & $37 \mathrm{~d}$ \\
\hline $\mathrm{CV}(\%)$ & 10.79 & 9.85 & 10.41 & 9.74 & 11.09 & 10.39 \\
\hline
\end{tabular}

In a column, mean values having common letter(s) do not differ significantly whereas mean values with dissimilar letter(s) differ significantly as per DMRT. 
showed more or less static although production of TDM was less. The result is in agreement with Biswas (2011). The authors stated that $75 \%$ variation of tuber yield could be explained by the functional relationship of above ground total dry matter under both fertilized and unfertilized conditions.

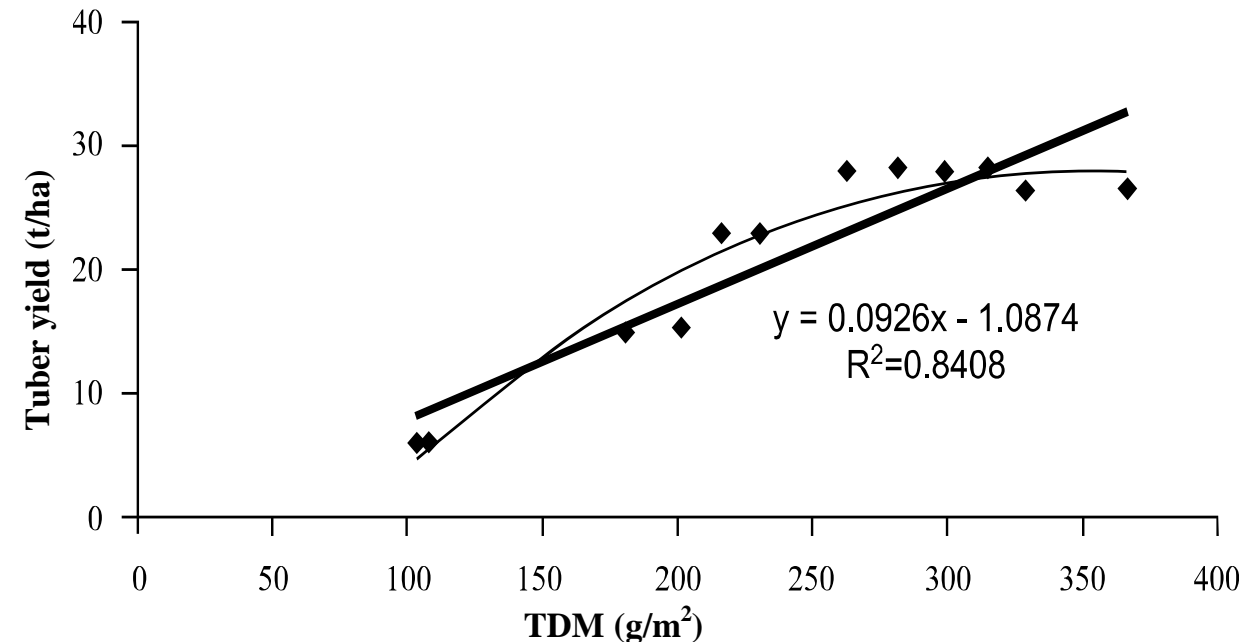

Fig. 1. Functional relationship between TDM at $60 \mathrm{DAP}$ and tuber yield of potato as influenced by nutrient treatments (two years' data).

\section{Mungbean}

Significant variation in total dry matter production of mungbean was noticed among the nutrient levels at all days after sowing (DAS) in both the years (Table 3).

The highest TDM content at 30,40, 50,60, 70, and 80 DAS was found in HYG+CRI, which was statistically identical to HYG and IPNS+CRI in 2007. The lowest TDM was recorded in control plot without CRI. Similar trend was observed for TDM production in 2008.

Total dry matter production of mungbean was increased progressively with the advancement of time irrespective of nutrient levels up to 70 DAS in both the years. The trend was decreasing at 80 DAS that might be due to leaf senescence. The results showed that the treatment HYG without or with CRI gave the maximum TDM at all DAS which might be due to the effect of higher nutrient added especially nitrogen that helped to enhance more plant growth as well as total dry matter production. Those results were followed by IPNS and STB treatments without or with CRI. Whereas, MYG and FP treatments without or with CRI produced less TDM compared to HYG, IPNS, and STB treatments along with or without CRI that might be due to the effect of respective nutrient management. Control treatment without CRI produced the lowest TDM due to low nutrient content in the soil i.e., native nutrient only. More or less similar 
trend was observed in both the years. However, TDM production was slightly higher in those plots where crop residues were incorporated which might be due to addition of extra nutrient to the soil through the crop residues incorporation, although that amount was not remarkable compared to original treatments. Similar results were also reported by Mian (2008).

Table 3. Total dry matter $\left(\mathrm{g} / \mathrm{m}^{2}\right)$ of mungbean at different days after sowing as influenced by various nutrient management treatments.

\begin{tabular}{l|c|c|c|c|c|c}
\hline \multirow{2}{*}{$\begin{array}{c}\text { Nutrient } \\
\text { management }\end{array}$} & \multicolumn{2}{c|}{30 DAS } & \multicolumn{2}{c|}{40 DAS } & \multicolumn{2}{c}{50 DAS } \\
\cline { 2 - 7 } & 2007 & 2008 & 2007 & 2008 & 2007 & 2008 \\
\hline HYG & $89 \mathrm{a}$ & $96 \mathrm{a}$ & $301 \mathrm{a}$ & $315 \mathrm{~b}$ & $692 \mathrm{ab}$ & $712 \mathrm{a}$ \\
MYG & $31 \mathrm{c}$ & $35 \mathrm{c}$ & $202 \mathrm{c}$ & $213 \mathrm{~cd}$ & $551 \mathrm{~b}$ & $597 \mathrm{a}$ \\
IPNS & $65 \mathrm{~b}$ & $72 \mathrm{~b}$ & $283 \mathrm{ab}$ & $302 \mathrm{~b}$ & $632 \mathrm{ab}$ & $669 \mathrm{a}$ \\
STB & $63 \mathrm{~b}$ & $71 \mathrm{~b}$ & $261 \mathrm{abc}$ & $274 \mathrm{bc}$ & $653 \mathrm{ab}$ & $665 \mathrm{a}$ \\
FP & $32 \mathrm{c}$ & $34 \mathrm{c}$ & $202 \mathrm{c}$ & $206 \mathrm{~cd}$ & $321 \mathrm{c}$ & $342 \mathrm{~b}$ \\
CON & $23 \mathrm{c}$ & $32 \mathrm{c}$ & $113 \mathrm{~d}$ & $126 \mathrm{e}$ & $312 \mathrm{c}$ & $333 \mathrm{~b}$ \\
HYG+CRI & $102 \mathrm{a}$ & $105 \mathrm{a}$ & $321 \mathrm{a}$ & $394 \mathrm{a}$ & $713 \mathrm{a}$ & $723 \mathrm{a}$ \\
MYG+CRI & $34 \mathrm{c}$ & $35 \mathrm{c}$ & $225 \mathrm{bc}$ & $236 \mathrm{~cd}$ & $583 \mathrm{ab}$ & $603 \mathrm{a}$ \\
IPNS+CRI & $88 \mathrm{a}$ & $93 \mathrm{a}$ & $285 \mathrm{ab}$ & $305 \mathrm{~b}$ & $685 \mathrm{ab}$ & $701 \mathrm{a}$ \\
STB+CRI & $72 \mathrm{~b}$ & $76 \mathrm{~b}$ & $281 \mathrm{ab}$ & $304 \mathrm{~b}$ & $656 \mathrm{ab}$ & $677 \mathrm{a}$ \\
FP+CRI & $33 \mathrm{c}$ & $37 \mathrm{c}$ & $207 \mathrm{c}$ & $220 \mathrm{~cd}$ & $328 \mathrm{c}$ & $456 \mathrm{~b}$ \\
CON+CRI & $26 \mathrm{c}$ & $34 \mathrm{c}$ & $117 \mathrm{~d}$ & $191 \mathrm{~d}$ & $315 \mathrm{c}$ & $388 \mathrm{~b}$ \\
\hline CV $(\%)$ & 11.47 & 11.38 & 10.99 & 10.59 & 10.54 & 10.59 \\
\hline
\end{tabular}

Table 3. Cont'd.

\begin{tabular}{l|cc|c|c|c|c}
\hline \multirow{2}{*}{$\begin{array}{l}\text { Nutrient } \\
\text { management }\end{array}$} & \multicolumn{2}{c|}{$60 \mathrm{DAS}$} & \multicolumn{2}{c|}{$70 \mathrm{DAS}$} & \multicolumn{2}{c}{$80 \mathrm{DAS}$} \\
\cline { 2 - 7 } HYG & 2007 & 2008 & 2007 & 2008 & 2007 & 2008 \\
MYG & $824 \mathrm{a}$ & $848 \mathrm{a}$ & $805 \mathrm{a}$ & $820 \mathrm{ab}$ & $702 \mathrm{a}$ & $722 \mathrm{a}$ \\
IPNS & $417 \mathrm{~cd}$ & $437 \mathrm{def}$ & $519 \mathrm{~b}$ & $559 \mathrm{de}$ & $451 \mathrm{~b}$ & $406 \mathrm{de}$ \\
STB & $592 \mathrm{~b}$ & $612 \mathrm{~b}$ & $601 \mathrm{~b}$ & $617 \mathrm{~cd}$ & $517 \mathrm{~b}$ & $538 \mathrm{bc}$ \\
FP & $582 \mathrm{~b}$ & $587 \mathrm{bc}$ & $605 \mathrm{~b}$ & $607 \mathrm{cde}$ & $537 \mathrm{~b}$ & $482 \mathrm{bcd}$ \\
CON & $415 \mathrm{~cd}$ & $435 \mathrm{def}$ & $303 \mathrm{c}$ & $323 \mathrm{fg}$ & $290 \mathrm{c}$ & $305 \mathrm{ef}$ \\
HYG+CRI & $290 \mathrm{~d}$ & $304 \mathrm{f}$ & $276 \mathrm{c}$ & $290 \mathrm{~g}$ & $201 \mathrm{c}$ & $208 \mathrm{f}$ \\
MYG+CRI & $845 \mathrm{a}$ & $873 \mathrm{a}$ & $821 \mathrm{a}$ & $914 \mathrm{a}$ & $712 \mathrm{a}$ & $847 \mathrm{a}$ \\
IPNS+CRI & $837 \mathrm{c}$ & $527 \mathrm{bcd}$ & $522 \mathrm{~b}$ & $581 \mathrm{cde}$ & $470 \mathrm{~b}$ & $468 \mathrm{bcd}$ \\
STB+CRI & $716 \mathrm{ab}$ & $840 \mathrm{a}$ & $611 \mathrm{~b}$ & $812 \mathrm{ab}$ & $526 \mathrm{~b}$ & $544 \mathrm{~b}$ \\
FP+CRI & $422 \mathrm{~cd}$ & $462 \mathrm{cde}$ & $313 \mathrm{c}$ & $581 \mathrm{cde}$ & $305 \mathrm{c}$ & $411 \mathrm{cde}$ \\
CON+CRI & $305 \mathrm{~cd}$ & $373 \mathrm{ef}$ & $281 \mathrm{c}$ & $452 \mathrm{ef}$ & $207 \mathrm{c}$ & $279 \mathrm{f}$ \\
\hline CV $(\%)$ & 10.64 & 10.42 & 10.76 & 10.41 & 10.70 & 10.89 \\
\hline
\end{tabular}

In a column, mean values having common letter(s) do not differ significantly whereas mean values with dissimilar letter(s) differ significantly as per DMRT. 
HYG $($ High Yield Goal) $=0-24-40-48-24-3-1.2$, MYG $($ Moderate Yield Goal $)=0$ 20-36-40-20-2-1, IPNS (Integrated Plant Nutrient System)=5000-9-37-36-21-31.2, STB (Soil Test Based) $=0-20-36-40-22-2-1$, FP (Farmer's practice $)=0-6-5-4-$ $0-0-0, \mathrm{CON}=0-0-0-0-0-0-0, \mathrm{CD}, \mathrm{N}, \mathrm{P}, \mathrm{K}, \mathrm{S}, \mathrm{Zn}, \mathrm{B}(\mathrm{kg} / \mathrm{ha})$, respectively, and $\mathrm{CRI}=$ Crop residue incorporation.

\section{Functional relationship between TDM and seed yield of mungbean}

Regression analysis (mean of two years data) was done to determine the relationship between total dry matter (TDM) at 60 DAS and seed yield of mungbean and the maximum TDM $\left(\mathrm{g} / \mathrm{m}^{2}\right)$ from above ground portion was produced at $60 \mathrm{DAS}$ in both the years that was influenced by different nutrient management practices during the total growth period of the crop. Therefore, this stage (60 DAS) was considered to make a functional relationship between TDM and seed yield (two years' mean data). There was a positive linear relationship between TDM at 60 DAS and seed yield (Fig. 2). The relationship was significant at $\mathrm{p} \leq 0.01$. The functional relationship between total dry matter and seed yield implies that $64 \%\left(\mathrm{R}^{2}=0.6434\right)$ of the variation in total seed yield was explained from the variation in total dry matter at 60 DAS. On average, the seed yield could be increased at the rate of $0.002 \mathrm{t} / \mathrm{ha}$ with an increase in $1 \mathrm{~g} / \mathrm{m}^{2}$ of TDM at 60 DAS. From the non-liner curve, it was observed that maximum seed yield of mungbean was gained when TDM production was nearly $750 \mathrm{~g} \mathrm{~m}^{-2}$ at 60 DAS then the trend showed declining and TDM production was also less. Similar result was observed by Saha (2005) in BARI Mung-5 and BU Mung-2 with higher nitrogen doses application.

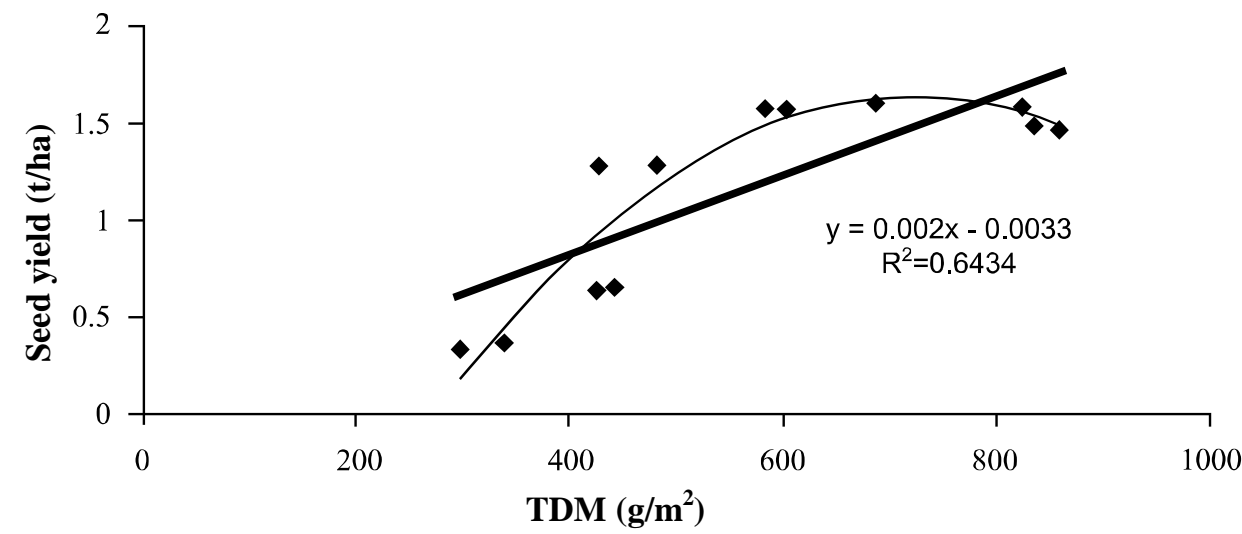

Fig. 2. Functional relationship between TDM at 60 DAS and seed yield of mungbean as influenced by nutrient treatments (two years' mean data).

\section{T.Aman rice}

TDM production was significantly influenced by different nutrient management treatments at various days after transplanting (DAT) in both the years (Table 4). 
The highest TDM at 30, 45, 60, 75, 90, and 105 DAT was recorded in HYG+CRI which was statistically identical to HYG in 2007. Control treatment without CRI produced the lowest TDM. The trend was almost similar in 2008. Maximum TDM was observed in HYG, IPNS, and STB treatments without or with CRI those were statistically identical. The lowest TDM was produced by control treatment without CRI.

TDM production was increased over time in all nutrient management treatments up to 90 DAT, afterwards the trend was nearly static in both the years. This result might be due to leaf senescence or even plant growth ceased at maturity stage. It revealed from Table 4 that the treatment HYG without or with CRI produced the maximum TDM at all DATs that might be due to effect of sufficient nutrient treatment which enhanced the vegetative growth as well as the total dry matter production of the plant. These results were followed by IPNS and STB treatments without or with CRI. The lowest TDM was recorded in control treatment without CRI at all DATs which might be due to the dependence of native nutrient only. However, the amount of TDM produced crop residues incorporation treatments was numerically higher than CRI treatments. This possibly happened due to nutrient supply from crop resides to the soil. Similar result was found by Mian (2008) and Islam (2008).

Table 4. Total dry matter $\left(\mathrm{g} / \mathrm{m}^{2}\right)$ of $T$.Aman rice at different days after transplanting as influenced by various nutrient management treatments.

\begin{tabular}{l|cc|c|c|cc}
\hline \multirow{2}{*}{$\begin{array}{c}\text { Nutrient } \\
\text { management }\end{array}$} & \multicolumn{2}{c|}{$30 \mathrm{DAT}$} & \multicolumn{2}{c|}{$45 \mathrm{DAT}$} & \multicolumn{2}{c}{$60 \mathrm{DAT}$} \\
\cline { 2 - 7 } & 2007 & 2008 & 2007 & 2008 & 2007 & 2008 \\
\hline HYG & $313 \mathrm{a}$ & $188 \mathrm{ab}$ & $695 \mathrm{a}$ & $557 \mathrm{a}$ & $1137 \mathrm{a}$ & $883 \mathrm{ab}$ \\
MYG & $180 \mathrm{~cd}$ & $143 \mathrm{~cd}$ & $453 \mathrm{cdef}$ & $337 \mathrm{bc}$ & $713 \mathrm{bc}$ & $694 \mathrm{cde}$ \\
IPNS & $228 \mathrm{bc}$ & $172 \mathrm{abcd}$ & $585 \mathrm{abc}$ & $364 \mathrm{bc}$ & $1010 \mathrm{ab}$ & $793 \mathrm{abcd}$ \\
STB & $193 \mathrm{~cd}$ & $155 \mathrm{abcd}$ & $547 \mathrm{bcd}$ & $356 \mathrm{bc}$ & $777 \mathrm{bc}$ & $667 \mathrm{cdef}$ \\
FP & $160 \mathrm{~d}$ & $135 \mathrm{de}$ & $368 \mathrm{efg}$ & $323 \mathrm{bc}$ & $593 \mathrm{c}$ & $534 \mathrm{ef}$ \\
CON & $147 \mathrm{~d}$ & $100 \mathrm{e}$ & $298 \mathrm{~g}$ & $293 \mathrm{c}$ & $562 \mathrm{c}$ & $499 \mathrm{f}$ \\
HYG+CRI & $342 \mathrm{a}$ & $192 \mathrm{a}$ & $698 \mathrm{a}$ & $591 \mathrm{a}$ & $1160 \mathrm{a}$ & $924 \mathrm{a}$ \\
MYG+CRI & $195 \mathrm{~cd}$ & $149 \mathrm{bcd}$ & $473 \mathrm{cde}$ & $409 \mathrm{~b}$ & $737 \mathrm{bc}$ & $712 \mathrm{bcde}$ \\
IPNS+CRI & $257 \mathrm{~b}$ & $177 \mathrm{abc}$ & $650 \mathrm{ab}$ & $520 \mathrm{a}$ & $1027 \mathrm{ab}$ & $833 \mathrm{abc}$ \\
STB+CRI & $232 \mathrm{bc}$ & $175 \mathrm{abcd}$ & $582 \mathrm{abc}$ & $416 \mathrm{~b}$ & $950 \mathrm{~b}$ & $754 \mathrm{abcd}$ \\
FP+CRI & $185 \mathrm{~cd}$ & $147 \mathrm{bcd}$ & $437 \mathrm{def}$ & $355 \mathrm{bc}$ & $730 \mathrm{bc}$ & $648 \mathrm{cdef}$ \\
CON+CRI & $178 \mathrm{~cd}$ & $100 \mathrm{e}$ & $335 \mathrm{fg}$ & $301 \mathrm{c}$ & $570 \mathrm{c}$ & $623 \mathrm{def}$ \\
\hline CV $\%$ \% & 10.49 & 10.54 & 10.71 & 10.29 & 10.74 & 10.24 \\
\hline
\end{tabular}


Table 4. Cont'd.

\begin{tabular}{l|c|c|c|c|c|c}
\hline \multirow{2}{*}{$\begin{array}{l}\text { Nutrient } \\
\text { management }\end{array}$} & \multicolumn{2}{c}{$75 \mathrm{DAT}$} & \multicolumn{2}{c}{$90 \mathrm{DAT}$} & \multicolumn{2}{c}{$105 \mathrm{DAT}$} \\
\cline { 2 - 7 } & 2007 & 2008 & 2007 & 2008 & 2007 & 2008 \\
\hline HYG & $1432 \mathrm{ab}$ & $1180 \mathrm{ab}$ & $1473 \mathrm{a}$ & $1657 \mathrm{ab}$ & $1463 \mathrm{a}$ & $1604 \mathrm{a}$ \\
MYG & $975 \mathrm{de}$ & $1019 \mathrm{~b}$ & $1002 \mathrm{bc}$ & $1183 \mathrm{def}$ & $995 \mathrm{~cd}$ & $1180 \mathrm{~cd}$ \\
IPNS & $1362 \mathrm{abc}$ & $1160 \mathrm{ab}$ & $1375 \mathrm{ab}$ & $1381 \mathrm{bcde}$ & $1300 \mathrm{ab}$ & $1290 \mathrm{bc}$ \\
STB & $1090 \mathrm{~cd}$ & $1155 \mathrm{ab}$ & $1100 \mathrm{bc}$ & $1371 \mathrm{bcde}$ & $1077 \mathrm{bc}$ & $1279 \mathrm{bc}$ \\
FP & $908 \mathrm{de}$ & $913 \mathrm{~b}$ & $910 \mathrm{cde}$ & $1062 \mathrm{ef}$ & $837 \mathrm{cde}$ & $1059 \mathrm{~cd}$ \\
CON & $703 \mathrm{e}$ & $804 \mathrm{~b}$ & $705 \mathrm{e}$ & $893 \mathrm{f}$ & $693 \mathrm{e}$ & $855 \mathrm{~d}$ \\
HYG+CRI & $1443 \mathrm{a}$ & $1138 \mathrm{a}$ & $1505 \mathrm{a}$ & $1706 \mathrm{a}$ & $1492 \mathrm{a}$ & $1684 \mathrm{a}$ \\
MYG+CRI & $1050 \mathrm{~d}$ & $1030 \mathrm{~b}$ & $1053 \mathrm{~cd}$ & $1327 \mathrm{cde}$ & $1027 \mathrm{bcd}$ & $1266 \mathrm{bc}$ \\
IPNS+CRI & $1393 \mathrm{ab}$ & $1187 \mathrm{ab}$ & $1457 \mathrm{a}$ & $1554 \mathrm{abc}$ & $1450 \mathrm{a}$ & $1543 \mathrm{ab}$ \\
STB+CRI & $1148 \mathrm{bcd}$ & $1169 \mathrm{ab}$ & $1158 \mathrm{bc}$ & $1422 \mathrm{abcd}$ & $1102 \mathrm{bc}$ & $1402 \mathrm{ab}$ \\
FP+CRI & $935 \mathrm{de}$ & $826 \mathrm{~b}$ & $960 \mathrm{~cd}$ & $1167 \mathrm{def}$ & $955 \mathrm{~cd}$ & $1124 \mathrm{~cd}$ \\
CON+CRI & $885 \mathrm{de}$ & $805 \mathrm{~b}$ & $890 \mathrm{de}$ & $1059 \mathrm{ef}$ & $740 \mathrm{de}$ & $860 \mathrm{~d}$ \\
\hline CV $(\%)$ & 10.43 & 10.21 & 10.47 & 9.76 & 10.38 & 9.23 \\
\hline
\end{tabular}

In a column, mean values having common letter(s) do not differ significantly whereas mean values with dissimilar letter(s) differ significantly as per DMRT.

HYG(High Yield Goal)=0-80-16-44-12-2-0, MYG (Moderate Yield Goal $)=0-56-12-32-8-1.5-0$, IPNS (Integrated Plant Nutrient System) $=5000-65-$ 13-32-9-2-0, STB (Soil Test Based) $=0-68-15-37-11-2-0$, FP (Farmer's practice $)=0-39-7-12-0-0-0, \mathrm{CON}=0-0-0-0-0-0-0, \mathrm{CD}, \mathrm{N}, \mathrm{P}, \mathrm{K}, \mathrm{S}, \mathrm{Zn}, \mathrm{B}(\mathrm{kg} / \mathrm{ha})$, respectively and $\mathrm{CRI}=\mathrm{Crop}$ residue incorporation.

\section{Functional relationship TDM and grain yield of t. aman rice}

To find out the relationship between total dry matter (TDM) at 90 DAT and the grain yield of t. aman rice regression analysis (two years' mean data) was done. More or less maximum TDM $\left(\mathrm{g} / \mathrm{m}^{2}\right)$ from above ground part was produced at 90 DAT in both the years as influenced by different nutrient management practices during the whole life cycle of the crop. Therefore, this stage (90 DAT) was considered to find out a functional relationship between TDM and grain yield (two years' mean data). It was observed that there was a positive linear relationship between TDM at 90 DAT and grain yield (Fig. 3). The relationship was significant at $\mathrm{p} \leq 0.01$. The functional relationship revealed that $68 \%$ $\left(\mathrm{R}^{2}=0.6889\right)$ of the variation in grain yield could be explained from the variation in total dry matter production at 90 DAT. On an average, grain yield could be 
increased at the rate of $0.0046 \mathrm{t} / \mathrm{ha}$ with an increase in $1 \mathrm{~g} / \mathrm{m}^{2}$ of TDM at 90 DAT. From the non-liner curve, it was reported that maximum grain yield was obtained when TDM production was approximately $1475 \mathrm{~g} / \mathrm{m}^{2}$ at 90 DAT after that the trend showed slightly decreased and TDM production was also less. Similar result was reported by Mian (2008) in t. aman rice with different nutrient management practices.

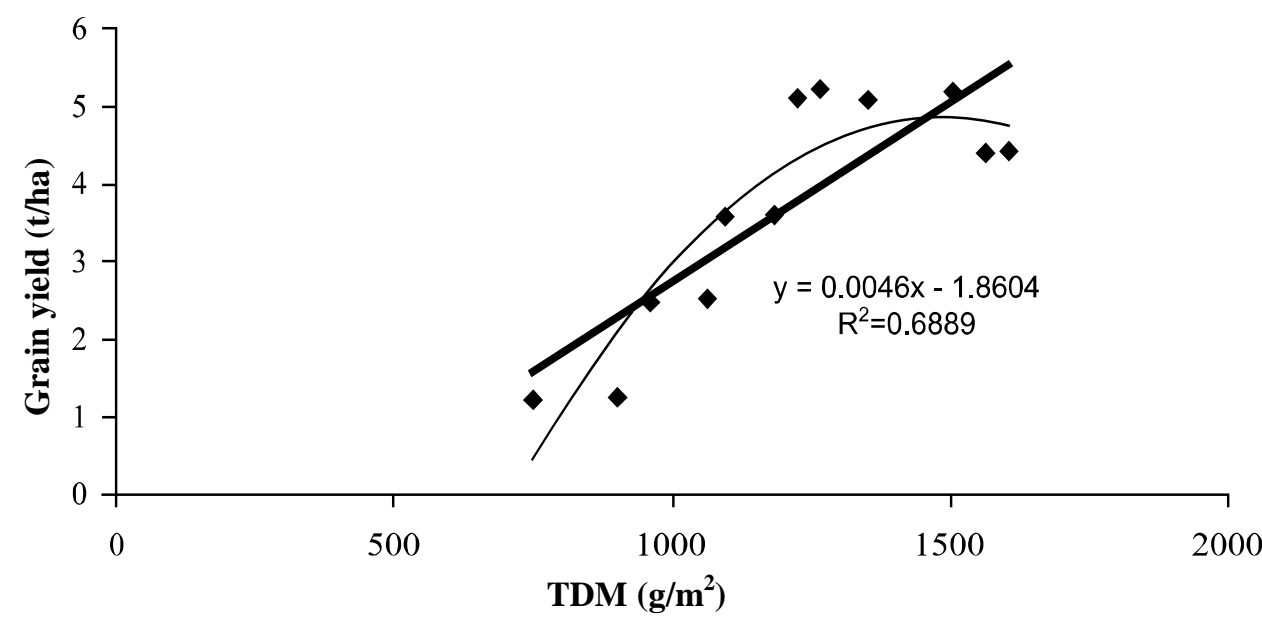

Fig. 3. Functional relationship between TDM at 90 DAT and grain yield of $t$. aman rice as influenced by nutrient treatments (two years' mean data).

\section{Yield}

Potato: The highest tuber yield $(27.64 \mathrm{t} / \mathrm{ha})$ was obtained from the treatment STB+CRI, which were statistically identical to a number of treatments like STB, IPNS, and HYG with or without CRI. The lowest yield was found in control plot in 2006-07 (Table 6). Similar trend was observed in the consecutive year 200708 . However, increasing trend of tuber yield was noticed in second year might be due to extra nutrient was added from crop residue management (Table 1). This result was observed might be due to the optimum nutrient management. The result was in agreement with Hossain et al., 2008.

Mungbean: STB+CRI treatment gave the highest seed yield (1.57 t/ha) that was statistically identical to STB, IPNS, IPNS+CRI, HYG, and HYG+CRI. Control plot produced the lowest seed yield in 2007 (Table 6). The trend was similar in 2008. However, seed yield showed increasing trend in second year might be due to the additional nutrient came from crop residue management (Table 1). This result was found might be due to the proper nutrient management. Similar result was reported by Akhterruzzaman et al., 2009. 
Table 6. Yield of potato, mungbean, and t. aman rice as influenced by nutrient managements during 2006-07 and 2007-08.

\begin{tabular}{|c|c|c|c|c|c|c|c|c|c|}
\hline \multirow{2}{*}{$\begin{array}{c}\text { Nutrient } \\
\text { management }\end{array}$} & \multicolumn{3}{|c|}{ Tuber yield of potato $(\mathrm{t} / \mathrm{ha})$} & \multicolumn{3}{|c|}{ Seed yield of mungbean ( $\mathrm{t} / \mathrm{ha})$} & \multicolumn{3}{|c|}{ Grain yield of $t$. aman rice ( $t / h a)$} \\
\hline & $2006-07$ & 2007-08 & Mean & 2007 & 2008 & Mean & 2007 & 2008 & Mean \\
\hline HYG & $26.12 \mathrm{a}$ & $27.01 \mathrm{a}$ & 26.57 & $1.41 \mathrm{ab}$ & $1.48 \mathrm{ab}$ & 1.45 & $4.31 \mathrm{ab}$ & $4.51 \mathrm{ab}$ & 4.41 \\
\hline MYG & $23.55 \mathrm{~b}$ & $22.40 \mathrm{~b}$ & 22.98 & $1.24 \mathrm{~b}$ & $1.30 \mathrm{~b}$ & 1.27 & $3.50 \mathrm{~b}$ & $3.70 \mathrm{~b}$ & 3.60 \\
\hline IPNS & $26.83 \mathrm{a}$ & $28.66 \mathrm{a}$ & 27.75 & $1.52 \mathrm{a}$ & $1.69 \mathrm{a}$ & 1.61 & $4.93 \mathrm{a}$ & $5.13 \mathrm{a}$ & 5.03 \\
\hline STB & $27.10 \mathrm{a}$ & $28.95 \mathrm{a}$ & 28.03 & $1.54 \mathrm{a}$ & $1.71 \mathrm{a}$ & 1.63 & $5.02 \mathrm{a}$ & $5.22 \mathrm{a}$ & 5.12 \\
\hline FP & $14.57 \mathrm{c}$ & $15.76 \mathrm{c}$ & 15.17 & $0.63 \mathrm{c}$ & $0.71 \mathrm{c}$ & 0.67 & $2.41 \mathrm{c}$ & $2.61 \mathrm{c}$ & 2.51 \\
\hline $\mathrm{CON}$ & $6.08 \mathrm{~d}$ & $6.11 \mathrm{~d}$ & 6.10 & $0.33 \mathrm{~d}$ & $0.38 \mathrm{~d}$ & 0.36 & $1.21 \mathrm{~d}$ & $1.31 \mathrm{~d}$ & 1.26 \\
\hline HYG+CRI & $26.25 \mathrm{a}$ & $27.15 \mathrm{a}$ & 26.70 & $1.44 \mathrm{ab}$ & $1.51 \mathrm{ab}$ & 1.48 & $4.35 \mathrm{ab}$ & $4.55 \mathrm{ab}$ & 4.45 \\
\hline MYG+CRI & $23.67 \mathrm{~b}$ & $22.52 \mathrm{~b}$ & 23.10 & $1.26 \mathrm{~b}$ & $1.32 \mathrm{~b}$ & 1.29 & $3.54 \mathrm{~b}$ & $3.73 \mathrm{~b}$ & 3.64 \\
\hline IPNS+CRI & $27.35 \mathrm{a}$ & $28.69 \mathrm{a}$ & 28.02 & $1.54 \mathrm{a}$ & $1.70 \mathrm{a}$ & 1.62 & $5.03 \mathrm{a}$ & $5.23 \mathrm{a}$ & 5.13 \\
\hline STB+CRI & $27.64 \mathrm{a}$ & $28.98 \mathrm{a}$ & 28.31 & $1.57 \mathrm{a}$ & $1.73 \mathrm{a}$ & 1.65 & $5.14 \mathrm{a}$ & $5.34 \mathrm{a}$ & 5.24 \\
\hline $\mathrm{FP}+\mathrm{CRI}$ & $14.64 \mathrm{c}$ & $15.84 \mathrm{c}$ & 15.24 & $0.64 \mathrm{c}$ & $0.72 \mathrm{c}$ & 0.68 & $2.43 \mathrm{c}$ & $2.64 \mathrm{c}$ & 2.54 \\
\hline $\mathrm{CON}+\mathrm{CRI}$ & $6.11 \mathrm{~d}$ & $6.13 \mathrm{~d}$ & 6.12 & $0.36 \mathrm{~d}$ & $0.41 \mathrm{~d}$ & 0.39 & $1.26 \mathrm{~d}$ & $1.36 \mathrm{~d}$ & 1.31 \\
\hline Levl. Sig. & $* *$ & $* *$ & & $* *$ & $* *$ & & $* *$ & $* *$ & \\
\hline $\mathrm{CV}(\%)$ & 6.39 & 9.29 & & 7.51 & 10.27 & & 9.76 & 9.29 & \\
\hline
\end{tabular}




\section{T.Aman rice}

The highest grain yield was found in STB+CRI (5.14 t/ha), which was statistically identical to STB, IPNS, and HYG with or without CRI. The yield was observed in control plot in 2007 (Table 6). Similar trend was also noticed in 2008. However, grain yield showed increasing trend in the next year might be due to extra nutrient added from crop residue management (Table 1). This result was found might be due to the proper nutrient management. The result was in agreement with Timsina et.al., 2006.

\section{Conclusion}

HYG treatment without or with crop residues incorporation produced the highest TDM in potato, mungbean, and t. aman rice followed by IPNS and STB along with or without CRI. The lowest TDM was recorded in control plot without CRI. The increasing trend of TDM was observed in the crop residues incorporation plots than non-incorporation plots. It was observed that there were significant and positive linear relationship between TDM and yield of potato tuber, mungben seed, and grain yield of rice at 60 DAP, 60 DAS, and 90 DAT, respectively, in both the years.

\section{References}

Akhteruzzaman, M., N. A. Mondal, K. U. Ahammad, J. A. Mahmud and M.A. H. S. Jahan. 2009. Integrated nutrient management for Wheat-Mungbean-T. aman rice cropping pattern in high Ganges river floodplain soil. Eco-friendly Agril. J. 2(1): 322-326.

BBS (Bangladesh Bureau of Statistics). 2011. Statistical Year Book of Bangladesh. Bangladesh Bur. Stat., Plan. Div., Minis. Plan., Govt. People's Repub. Bangladesh. Dhaka, Bangladesh. Pp. 27-29.

Biswas, S. K. 2011. Effect of irrigation with municipal waste water on wheat and potato cultivation. Ph. D Dissertation. Department of Irrigation and Water Management. Bangladesh Agricultural University, Mymensingh, Bangladesh. Pp. 217.

Couto, F. A. A., L.C. Sikka and S.P.R. Weerasinghe. 1983. The potato in the lower tropics. In : W. J. Hooker (ed.) " Research for the potato in the year 2000". International Potato Centre (CIP), Lima, Peru. Pp.5-10.

Harwood, R. R. 1974. Resource utilization approach to cropping system improvement. International workshop on Farming Systems, 18-21 November 1974, ICRISAT, Hydarabad, India.

Hossain, M. F., M. A. Salam, M. S. Hossain, M. Badirul Islam and M.S. Islam. 2008. Nutrient management for Potato-Fallow-T. aman rice cropping pattern at high Barind tract. Int. J. Sustain. Agril. Tech. 4(3): 86-91.

Islam, M. S. 2008. Effect of some green manuring crops and levels of nitrogen on the growth, yield, and nitrogen uptake in transplanted aman Rice and subsequent Wheat 
crop. Ph D Thesis. Institute of Biological Sciences. Rajshahi University, Rajshahi, Bangladesh. Pp.296.

Kaul, A. K.1980. Annual Report, Plant Breeding Division. BARI, Joydebpur, Dhaka.

Mian, M. A. K. 2008. Performance of maize oriented cropping patterns under different nutrient management. Ph D Thesis. Dept. of Agronomy. Bangladesh Agricultural University, Mymensingh. P. 220.

Saha, R. R. 2005. Ph D Thesis. Physiological aspects of yield and seed quality of mungbean (Vigna radita (L.) WILCZEK). Department of Agronomy. Bangabandhu Sheikh Mujibur Rahman Agricultural University, Gazipur, Bangladesh. Pp.158.

Satter, M A, Rahman, M. A, Rashid, H.U, Ali, M.S and Alom, M.S. 2005. Krishi Projukti Hatboi (Handbook on Agro-technology), $3^{\text {rd }}$ edition, Bangladesh Agricultural Research Institute, Gazipur-1701, Bangladesh. Pp. 1-559.

Timsina, J., M. A. Quayyum, D.J. Connor, M. Saleque, F. Haq, G.M. Panaullah, M.A. H.S. Jahan and R.A. Begum. 2006. Effect of fertilizer and mungbean residue management on total productivity, soil fertility and N-use efficiency of intensified Rice-Wheat systems. International Journal of Agricultural Research 1(1): 41-52.

Woolfe, J.A.1987. The potato of the human diet. Published in collaboration with international potato centre, Cambridge University Press. Cambridge London, New York, New Rochelle, Melbourne, Sydney. Pp. 26-31. 